\title{
Slower rise of exhaled breath temperature in chronic obstructive pulmonary disease
}

\author{
P. Paredi*, G. Caramori", D. Cramer", S. Ward", A. Ciaccia", A. Papi", S.A. Kharitonov*, P.J. Barnes*
}

Slower rise of exhaled breath temperature in chronic obstructive pulmonary disease. P. Paredi, G. Caramori, D. Cramer, S. Ward, A. Ciaccia, A. Papi, S.A. Kharitonov, P.J. Barnes. C) ERS Journals Ltd 2003.

ABSTRACT: In chronic obstructive pulmonary disease (COPD) there is decreased vascularity of the bronchi and inflammation of the airways that may have opposite effects on the regulation of heat loss.

Exhaled air temperature increase $\left(\Delta \mathrm{e}^{\circ} \mathrm{T}\right)$ was measured in 23 patients with moderate COPD (18 male, mean age \pm SEM $70 \pm 1$ yrs; forced expiratory volume in one second (FEV1) 45 $\pm 3 \%$, FEV1/forced vital capacity $54 \pm 4 \%$ ) and 16 normal volunteers $(64 \pm 4 \mathrm{yr})$ and compared to exhaled nitric oxide (eNO) and inflammatory cells in induced sputum as a marker of airway inflammation. $\Delta \mathrm{e}^{\circ} \mathrm{T}$ was measured during a flowand pressure-controlled single exhalation with a fast-response thermometer.

$\Delta \mathrm{e}^{\circ} \mathrm{T}$ was reduced in patients with $\mathrm{COPD}\left(1.86 \pm 0.15 \Delta \Delta^{\circ} \cdot \mathrm{s}^{-1}\right)$ compared to normal subjects $\left(4.00 \pm 0.26 \Delta^{\circ} \mathrm{C} \cdot \mathrm{s}^{-1}\right)$. There was no difference in $\Delta \mathrm{e}^{\circ} \mathrm{T}$ between patients treated with inhaled steroids and those who were steroid naïve. $\Delta \mathrm{e}^{\circ} \mathrm{T}$ was correlated with eNO ( $r=0.60)$ but not with sputum neutrophilia. In COPD patients, $\Delta e^{\circ} T$ was increased $\left(2.26 \pm 0.16 \Delta \Delta^{\circ} \cdot \mathrm{s}^{-1}\right)$ after the inhalation of $200 \mu \mathrm{g}$ of albuterol, which is a known vasodilator, indicating that $\Delta \mathrm{e}^{\circ} \mathrm{T}$ and bronchial blood flow may be correlated.

Exhaled temperature increase is reduced in chronic obstructive pulmonary disease patients and is increased by the inhalation of vasodilators and therefore may be related to changes of bronchial blood flow and tissue remodelling.

Eur Respir J 2003; 21: 439-443.
*Dept of Thoracic Medicine, Imperial College School of Medicine at the National Heart and Lung Institute and ${ }^{\#}$ Lung Function Unit, Royal Brompton Hospital, London, UK. "Respiratory Unit University of Ferrara, Ferrara, Italy.

Correspondence: P.J. Barnes, Dept of Thoracic Medicine, National Heart and Lung Institute, Dovehouse Street, London, SW3 6LY, UK.

Fax: 442073515675

E-mail: p.j.barnes@ic.ac.uk

Keywords: Breath temperature, bronchial blood flow, chronic obstructive pulmonary disease, nitric oxide

Received: July 102002

Accepted after revision: October 16 2002

This study was supported by the National Heart and Lung Institute, London, UK.
Chronic obstructive pulmonary disease (COPD) is characterised by progressive, largely irreversible airflow limitation, leading to considerable disability and mortality [1]. Histological examination of the airway wall has shown decreased bronchial vascularity $[2,3]$. These changes contribute to airway remodelling and may play a pathogenic role. Clinical features that are typical of COPD, such as hypoxia, hypercapnia and pulmonary hypertension, may also influence peripheral haemodynamics. However, although some studies have investigated systemic blood flow in COPD patients [4], the airway circulation and its affect on heat transfer across the bronchial wall has not yet been elucidated.

The bronchial circulation arises from the aorta and forms a dense peribronchial plexus of interconnecting vessels. Branches then penetrate the muscular layer to form a second network in the submucosa. Capillary engorgement and/or leakage in this circulatory bed could directly alter airway wall thickness. Inflammatory mediators released in COPD may contribute to bronchial vasodilation [5] and potential candidates include bradykinin [6], prostaglandins [7] and neuropeptides released by sensory nerves [8]. Platelet-activating factor (PAF) may also increase bronchial vascular blood flow [9]. Bronchial blood flow may be reduced because of the low bronchial vascularity [2], the vasoconstrictive effect of endothelins [10] and hyperinflation, which decreases bronchial blood flow. The final bronchial blood flow may depend on the balance between pro-inflammatory mediators causing vasodilation and decreased bronchial vascularity reducing bronchial blood flow.

The authors hypothesised that, because of airway inflammation and structural changes, patients with COPD would have an alteration of the bronchial blood flow. Considering that mucosal blood flow is the major contributor to airway temperature, exhaled breath temperature and the effect of the vasodilator salbutamol in patients with COPD were measured. In addition, because inflammation may modify bronchial blood flow, the correlation between exhaled breath temperature and inflammation as assessed by exhaled nitric oxide (eNO) and induced sputum was investigated [11].

\section{Methods}

\section{Patients}

All the patients enrolled met the Global Initiative for Chronic Obstructive Lung Disease criteria for the diagnosis of COPD [12] (table 1) and had moderate COPD. The patients enrolled in the study had a moderate degree of emphysema, as assessed by the carbon monoxide transfer coefficient controlled for alveolar ventilation in 15 patients and computed tomography $(\mathrm{CT})$ scan in six patients. Furthermore, all the patients were exsmokers with a history of smoking equivalent to $\geqslant 20$ pack-yrs. The current smoking status of all the subjects was confirmed by nicCheck I (DynaGen Inc; Cambridge, MA, USA), which detects nicotine and its metabolites in the urine. Active and passive smokers (smoke exposure for $>0.5 \mathrm{~h} \cdot \mathrm{day}^{-1}$ ) were excluded from the study. None of the patients had a history of atopy or a significant reversibility of airflow obstruction $(>15 \%$ or $>200 \mathrm{~mL})$ after inhalation of $400 \mu \mathrm{g}$ albuterol via a metered-dose inhaler. The patients were 
Table 1.-Patient characteristics

\begin{tabular}{lccc}
\hline & $\begin{array}{c}\text { Not steroid } \\
\text { treated }\end{array}$ & $\begin{array}{c}\text { Steroid } \\
\text { treated }\end{array}$ & Controls \\
\hline Subjects n & 9 & 14 & 16 \\
Age yrs & $68 \pm 4$ & $72 \pm 2$ & $64 \pm 4$ \\
Sex M:F & $9: 9$ & $13: 1$ & $12: 4$ \\
KCO \% pred & $65 \pm 10^{\#}$ & $70 \pm 5^{\circ}$ & $\mathrm{NA}$ \\
FEV1\% pred & $51 \pm 8$ & $49 \pm 5$ & $95 \pm 9$ \\
Smokers & 0 & 0 & 0 \\
Exsmokers & 9 & 14 & 0 \\
Therapy & 9 & 14 & 0 \\
$\quad$ Inhaled $\beta$-adrenergics & 0 & 2 & 0 \\
$\quad$ Theophylline & 0 & 14 & 0 \\
$\quad$ Inhaled steroids & 0 & 0 & 0 \\
Oral steroids & 0 & & \\
\hline
\end{tabular}

Data are presented as means \pm SEM. M: male; F: female; KCO: carbon monoxide transfer coefficient; $\%$ pred: $\%$ predicted; FEV1: forced expiratory volume in one second; NA: not applicable. ${ }^{\#}$ : $n=5 ; ": n=6$.

in a stable state, with symptoms of COPD, especially the grade of dyspnoea and sputum volume, unchanged in the previous 3 months. All the patients enrolled in this study were afebrile. There was no history of cardiovascular diseases.

Altogether, 23 COPD patients (18 male, mean age \pm SEM $70 \pm 1$ yrs) all of whom were confirmed exsmokers, were studied (14 on steroid treatment for $\geqslant 3$ months). Steroid-treated patients were on inhaled fluticasone proprionate $500 \mu \mathrm{g} \cdot \mathrm{d}^{-1}$ $(n=5)$ and beclomethasone $500 \mu \mathrm{g} \cdot \mathrm{d}^{-1}(\mathrm{n}=9)$. None of the 16 nonsmoking controls (12 males, age $64 \pm 4 \mathrm{yrs}$ ), three of whom were included in a previous study [13], had a history of respiratory or cardiovascular disease. There was no history of upper respiratory tract infection for $\geqslant 4$ weeks before the study in all studied subjects and none of them had a clinical history of underlying vascular disease. All subjects had $\geqslant 30 \mathrm{~min}$ of rest before gas and exhaled breath temperature measurement, in order to eliminate the effect of any possible ambient contamination. All the measurements were made at baseline and $10 \mathrm{~min}$ after albuterol inhalation.

\section{Exhaled breath temperature measurement}

During a flow- and pressure-controlled exhalation from total lung capacity through a $2.77 \mathrm{~mm}$ mouthpiece [14], exhaled breath temperature was measured by a fast-response $(1 \mathrm{~ms})$, high-accuracy $\left(0.015 \pm 0.027^{\circ} \mathrm{C}\right)$ thermometer (Picotech Ltd, St Neots, UK) interfaced with a computer by a single-channel Picotech Oscilloscope (model ADC 42, resolution 12 bits; Picotech Ltd) allowing on-line recording of exhaled breath temperature. To minimise the effect of ambient temperature, all the subjects were asked to rest for $\geqslant 30 \mathrm{~min}$ in an air conditioned room at $23-24^{\circ} \mathrm{C}$. Furthermore, to reduce the effect of airway mechanics (turbulence and hence, temperature equilibrium between airway wall and airstream temperature) the exhalation flow rate was standardised at $10 \mathrm{~L} \cdot \mathrm{min}^{-1}$.

In a preliminary study, exhaled breath temperature tracings were analysed mathematically. The tracings proved to have an exponential rise and the point at $63 \%$ of the total temperature increase was chosen to study the slope of the curves because it represents two time constants of the maximal temperature $\left({ }^{\circ} \mathrm{T}\right)$ change and therefore allows a better mathematical characterisation of the tracings before plateau.

The time constant of the thermometer response was found by measuring the time it took the temperature to reach $63 \%$ of the final reading. This avoided large errors in estimating when the asymptotic final reading had been reached.
The exhaled breath temperature changed exponentially with time. The shape of the curve depended upon the time constant $(\mathrm{T})$. In one time constant, the response reached $63 \%$ of its final change.

The response was of the form:

$$
V(\mathrm{t})=\left(V_{2}-V_{1}\right)\left(1-\exp ^{(\mathrm{t} / \mathrm{T})}\right)
$$

where $V 2$ is the final value, $V 1$ the initial value, and $t$ is the time after exhalation was started. As $t$ was more than infinity, the exponential term was $>0$. Hence the response rose asymptotically to its final value. When performing experiments to determine the time response of a system, it is difficult to tell at which time the final value is obtained, since there will be a small change in the response for a relatively long time as the asymptote is approached. Jitter and noise in the signal add to this problem. It is easier to estimate the asymptotic value and find the time at which a certain percentage of this is reached. Various percentages are possible, but the most commonly used in physics and biology is the time constant, although in some applications (particularly electronic engineering) the rise time to $95 \%$ of the final value is used.

The $63 \%$ rises because when $\mathrm{t}$ is equal to $\mathrm{T}$, the expression above becomes:

$$
\begin{aligned}
& \left(V_{2}-V_{1}\right)(1-1 / \mathrm{e})=\left(V_{2}-V_{1}\right)(1-0.37) \\
& =0.63\left(V_{2}-V_{1}\right)
\end{aligned}
$$

In time constants, the percentage reached is $100 \times\left(1-1 / \mathrm{e}^{\mathrm{n}}\right)$, which approaches $98 \%$ after approximately five time constants.

The rate of temperature increase $\left(\Delta \mathrm{e}^{\circ} \mathrm{T}\right)$ calculated between the beginning of exhalation and $63 \%$ of the total temperature increase proved to be the most reproducible parameter to characterise the curves (fig. 1.).

The effects of the different exhalation flow rates, distance of the thermocouple from the edge of the mouthpiece and ambient temperature on $\Delta \mathrm{e}^{\circ} \mathrm{T}$ and end-expiratory plateau temperatures were evaluated. $\Delta \mathrm{e}^{\circ} \mathrm{T}$ but not plateau temperatures were elevated at low $\left(2-3 \mathrm{~L} \cdot \mathrm{min}^{-1}\right)$, compared to higher $\left(5-6 \mathrm{~L} \cdot \mathrm{min}^{-1}\right)$ exhalation flow rates $\left(6.25 \pm 0.4^{\circ} \mathrm{C} \cdot \mathrm{s}^{-1}\right.$ and $4.45 \pm$ $\left.0.8^{\circ} \mathrm{C} \cdot \mathrm{s}^{-1}, \mathrm{p}<0.01\right)$ in eight normal subjects. When the thermocouple was inserted $1 \mathrm{~cm}$ from the edge of the mouthpiece,

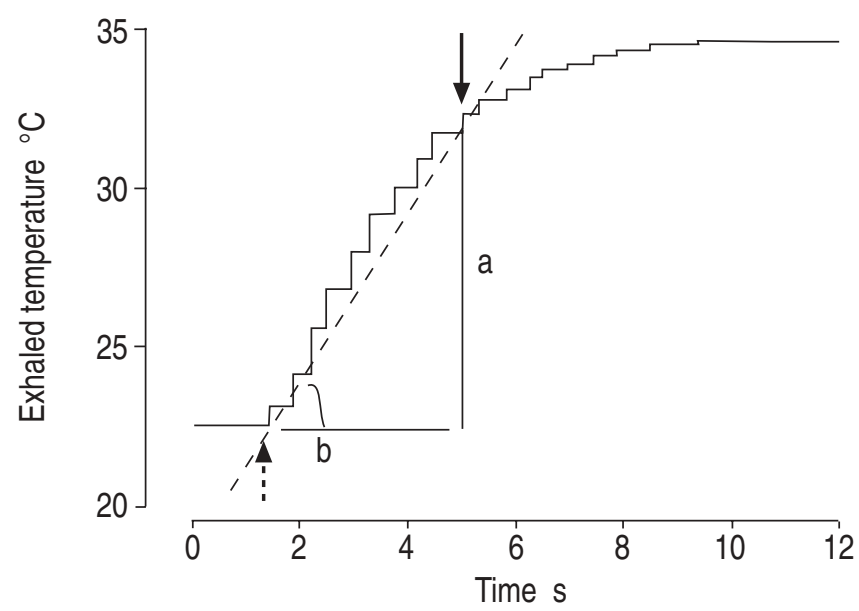

Fig. 1.-On-line recording of exhaled breath temperature of a normal subject. "a" represents the increase of temperature from baseline to $63 \%$ (two time constants) of the maximum increase and "b" is the time required to reach it. $a / b$ is the slope of the curve and represents the rate of temperature increase from baseline to $63 \%$ of the total temperature increase $\left(\Delta \mathrm{e}^{\circ} \mathrm{T}=2.8^{\circ} \mathrm{C}\right)$. Solid arrow: $63 \%$ of $\Delta^{\circ} \mathrm{T}$; broken arrow: start of exhalation. The plateau was $34.53^{\circ} \mathrm{C}$. Reproduced with permission from [14]. 
the $\Delta \mathrm{e}^{\circ} \mathrm{T}$ was significantly higher $\left(7.15 \pm 0.2^{\circ} \mathrm{C} \cdot \mathrm{s}^{-1}\right)$ compared to when it was located $2 \mathrm{~cm}$ from the edge of the mouthpiece $\left(4.45 \pm 0.8^{\circ} \mathrm{C} \cdot \mathrm{s}^{-1}, \mathrm{p}<0.01\right)$. There was a tendency for faster $\Delta \mathrm{e}^{\circ} \mathrm{T}$ when the subjects were starting exhalation from higher baseline ambient temperatures but this was not significant for temperature changes within $\pm 3^{\circ} \mathrm{C}\left(5.05 \pm 0.8^{\circ} \mathrm{C} \cdot \mathrm{s}^{-1}\right.$ at $28^{\circ} \mathrm{C}$ and $4.45 \pm 0.8^{\circ} \mathrm{C} \cdot \mathrm{s}^{-1}$ at $\left.22^{\circ} \mathrm{C}, \mathrm{p}>0.05\right)$. The volume ventilation did not influence the $\Delta \mathrm{e}^{\circ} \mathrm{T}$ value. Basal body temperature did not influence any of the breath temperature variables measured in this study. $\Delta \mathrm{e}^{\circ} \mathrm{T}$ was not statistically different in younger $(20 \pm 6 \mathrm{yrs}, \mathrm{n}=8)$ compared to older $(55 \pm 9 \mathrm{yrs}$, $n=6)$ subjects. As for the measurement of exhaled gases, the final plateau on the exhaled breath temperature tracing was assumed to correspond with the air coming from the lung parenchyma and therefore to the body core temperature.

The single-breath measurement of expired air temperature is reproducible when the exhalation flow rate, the distance of the thermocouple from the edge of the mouthpiece and the baseline exhalation temperature are standardised.

\section{Reproducibility}

The difference in $\Delta \mathrm{e}^{\circ} \mathrm{T}$ and plateau temperatures measured during two successive collections at 5-min intervals (single session coefficient of variation) was $4.4 \%(n=25)$, while the between-sessions coefficient of variation was $6.8 \%(n=6,1$-day interval). The reproducibility of the test was confirmed by the BLAND and ALTMAN [15] test, which showed that $>95 \%$ of the differences were $<2$ sDs.

Exhaled nitric oxide measurement. eNO was measured using a chemiluminescence analyser (model LR2000; Logan Research, Rochester, UK), sensitive to nitric oxide (NO) from $1-5,000$ parts per billion (ppb) by volume, as previously described [16]. The analyser was calibrated using certified NO mixtures (50 ppb) in nitrogen (BOC Special Gases, Guildford, UK). Measurements of eNO were made by slow exhalation $\left(5-6 \mathrm{~L} \cdot \mathrm{min}^{-1}\right)$ from total lung capacity for $20-30 \mathrm{~s}$ against a resistance $(3 \pm 0.4 \mathrm{mmHg})$.

Induced sputum. The sputum was induced by inhalation of hypertonic saline for 5-min periods up to $20 \mathrm{~min}$ and analysed as described previously [17]. Sputum plugs were incubated with $0.1 \%$ dithiothreitol until complete homogenisation. The cell suspension was filtered through $52 \mu$ m nylon gauze and then centrifuged at $800 \times g$ for $10 \mathrm{~min}$. The cell suspension was adjusted to a final concentration of 400,000 cells $\cdot \mathrm{mL}^{-1}$ and spun in a cytocentrifuge (Shandon Cytospin 2; Shandon, Oakland, CA, USA). Two slides were stained with Diff-Quick (Merz-Dade, Duningen, Switzerland) for differential cell counts of leukocytes and squamous epithelial cells.

\section{Statistics}

Comparisons between groups were made by two-way analysis of variance and data were expressed as mean \pm SEM and confidence intervals of differences. Significance was defined as a p-value of $<0.05$.

\section{Results}

\section{Exhaled breath temperature}

The end-expiratory plateau temperature was similar in COPD compared to normal subjects $\left(34.55 \pm 0.6^{\circ} \mathrm{C}\right.$ and $34.45 \pm 0.8^{\circ} \mathrm{C}$, respectively, $p>0.05$ ) and was not correlated with any of the lung function parameters.

$\Delta \mathrm{e}^{\circ} \mathrm{T}$ was lower in COPD patients compared to normal subjects $\left(1.86 \pm 0.15 \Delta \mathrm{C} \cdot \mathrm{s}^{-1}\right.$ versus $4.00 \pm 0.26 \Delta \mathrm{C} \cdot \mathrm{s}^{-1}$, respectively, $\mathrm{p}<0.01$; fig. 2 ).

There was a tendency for lower $\Delta \mathrm{e}^{\circ} \mathrm{T}$ in steroid-treated $\left(1.53 \pm 0.14 \Delta \mathrm{C} \cdot \mathrm{s}^{-1}\right)$ compared with untreated patients $(2.40 \pm$ $0.40 \Delta \mathrm{C} \cdot \mathrm{s}^{-1}$ ) but this was not significant.

$\Delta \mathrm{e}^{\circ} \mathrm{T}$ was increased after the inhalation of $200 \mu \mathrm{g}$ of salbutamol both in COPD patients $\left(1.68 \pm 0.15 \Delta \Delta^{\circ} \mathrm{C} \cdot \mathrm{s}^{-1}\right.$ to $2.26 \pm 0.16 \Delta^{\circ} \mathrm{C} \cdot \mathrm{s}^{-1}, \mathrm{p}<0.05$; fig. 3) and normal control subjects $\left(4.00 \pm 0.26 \Delta^{\circ} \mathrm{C} \cdot \mathrm{s}^{-1}\right.$ to $\left.7.80 \pm 0.41 \Delta^{\circ} \mathrm{C} \cdot \mathrm{s}^{-1}, \mathrm{p}<0.05\right)$.

$\Delta \mathrm{e}^{\circ} \mathrm{T}$ was not correlated with airway obstruction as assessed by forced expiratory volume in one second.

\section{Exhaled nitric oxide}

eNO levels were similarly elevated in steroid-treated (15.64 \pm $3.1 \mathrm{ppb})$ and untreated patients $(14.37 \pm 1.40 \mathrm{ppb})$ compared with the control group $(6.7 \pm 0.5 \mathrm{ppb}, \mathrm{p}<0.05)$ and were weakly correlated with the levels of exhaled $\Delta \mathrm{e}^{\circ} \mathrm{T}$ ( $\mathrm{r}=0.6, \mathrm{p}<0.05$; fig. 4).

There was a tendency for higher eNO concentrations in patients with a more relevant smoking history expressed as pack-yrs $(r=0.4, p>0.05)$ but this was not significant.

\section{Induced sputum}

The percentage of neutrophils was significantly higher in COPD patients $(72.81 \pm 4.6 \%, \mathrm{p}<0.05)$ compared to normal

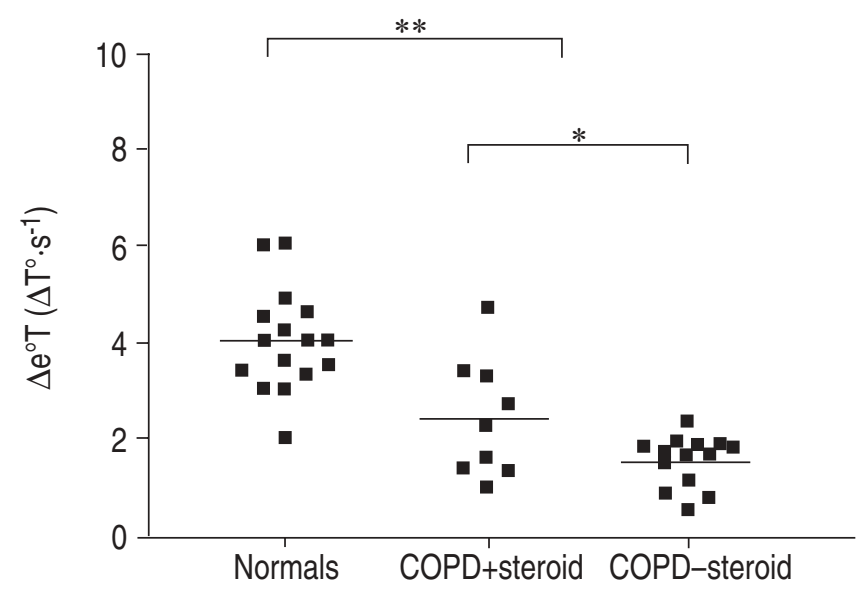

Fig. 2.-Exhaled breath temperature increase $\left(\Delta \mathrm{e}^{\circ} \mathrm{T}\right)$ in normal subjects and patients with chronic obstructive pulmonary disease (COPD). *: $\mathrm{p}<0.05 ; * *: \mathrm{p}<0.01$.

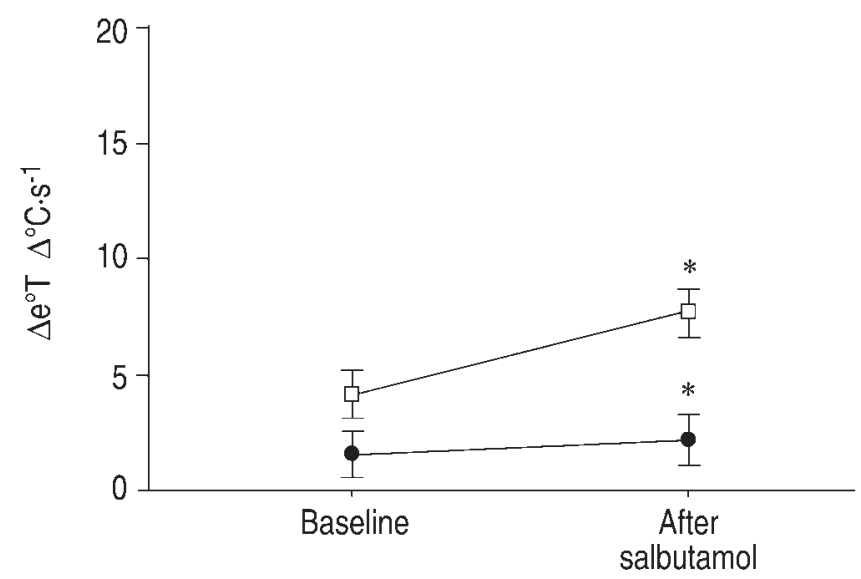

Fig. 3.-Exhaled breath temperature increase $\left(\Delta \mathrm{e}^{\circ} \mathrm{T}\right)$ in normal subjects $(\square)$ and chronic obstructive pulmonary disease (COPD; patients at baseline and after the inhalation of albuterol $200 \mu \mathrm{g}$. *: $\mathrm{p}<0.05$. 


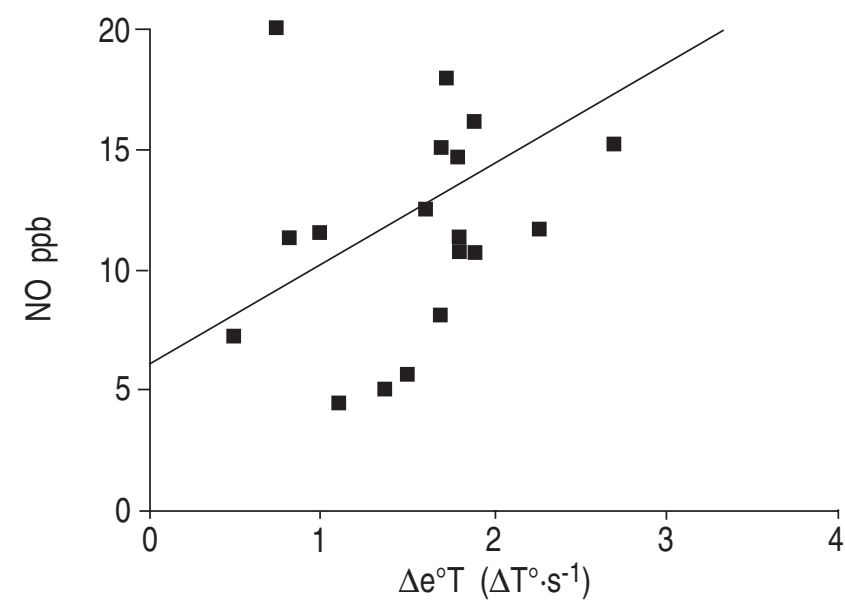

Fig. 4.-Correlation of exhaled breath temperature increase $\left(\Delta \mathrm{e}^{\circ} \mathrm{T}\right)$ and nitric oxide (NO) in patients with chronic obstructive pulmonary disease. ppb: parts per billion. $\mathrm{r}=0.6 ; \mathrm{p}<0.01$.

subjects $(40.61 \pm 5.5 \%, \mathrm{p}<0.05)$. The percentage eosinophil count was similar in COPD patients $(1.96 \pm 4.2 \%, \mathrm{p}<0.05)$ compared with normal controls $(0.96 \pm 4.27 \%, \mathrm{p}<0.05)$. However, two patients had elevated eosinophils counts $(4.4 \pm 2.1 \%)$ despite the absence of reversibility of bronchocostriction and normal skin-prick tests. The percentage of sputum macrophages was significantly lower in COPD patients $(17.51 \pm 3.40 \%)$ than in normal control subjects $(52.20 \pm 2.40 \%, \mathrm{p}<0.05)$. There were no correlations between cell counts and lung function tests or $\Delta \mathrm{C} \cdot \mathrm{s}^{-1}$ and $\mathrm{eNO}$.

\section{Discussion}

This study has demonstrated that patients with COPD have a reduced $\Delta \mathrm{e}^{\circ} \mathrm{T}$ compared to normal subjects. The authors suggest that this may reflect changes in bronchial blood flow and heat exchange resulting from inflammation and decreased vascularity of the bronchi.

Contrary to the authors' previous findings in asthma [13], where there was an increase in $\Delta \mathrm{e}^{\circ} \mathrm{T}$, in patients with COPD, there was a slower rise of breath temperature compared to normal subjects. This may reflect the decreased vascularity of the bronchial vessels [2] and reduced blood supply caused by intimal proliferation and hyperplasia [3]. CUDKOwICZ [3] performed the first post mortem bronchial arteriograms in 18 cases of emphysema and observed narrowing or obliteration of the intrapulmonary bronchial arteries with diminished pleural branches. In chronic bronchitis, microscopic examination revealed medial hyperplasia and intimal proliferation of varying severity. It was also established that the reduction of blood supply to the lung is the result and not the cause of emphysema [18]. It is noteworthy that contrary to the occurrences in pulmonary circulation, hypoxia induces bronchial vasodilation [19]. Therefore, this mechanism might not account for the lower exhaled breath temperature gradients found in COPD patients.

Changes in bronchial blood flow can alter airway responsiveness and airway temperature [20], indicating that the bronchial circulation may control air stream temperature and contribute to airway narrowing. In keeping with these findings [21], $\Delta \mathrm{e}^{\circ} \mathrm{T}$ increased in COPD patients after salbutamol inhalation, a known bronchial vasodilator [22]. This differs from the authors' previous findings, where the inhalation of salbutamol did not change $\Delta \mathrm{e}^{\circ} \mathrm{T}$ in asthma [13]. This is probably because in asthma, the vessels are already maximally dilated by inflammatory mediators and the bronchial blood flow cannot be further increased [22]. The finding of a lower post $\beta_{2} \Delta \mathrm{e}^{\circ} \mathrm{T}$ increase in COPD patients compared to normal subjects may support the hypothesis that COPD patients have reduced vascularity of the airways.

In this cross-sectional study, differences of $\Delta \mathrm{e}^{\circ} \mathrm{T}$ in corticosteroid-treated compared with untreated COPD patients were not shown, despite the vasoconstrictor activity of corticosteroids [23], and even though there was a tendency for lower $\Delta \mathrm{e}^{\circ} \mathrm{T}$ in steroid-treated patients. The authors suggest that the vasoconstrictive action of inhaled corticosteroids may have been balanced by $\beta_{2}$-induced vasodilation resulting in minimal changes in bronchial artery diameter and blood flow and, therefore, no net changes of $\Delta \mathrm{e}^{\circ} \mathrm{T}$. Further placebocontrolled studies are necessary to investigate the acute action and the time course of inhaled steroids on $\Delta \mathrm{e}^{\circ} \mathrm{T}$.

In COPD, the measurement of exhaled eNO as a noninvasive marker of inflammation has previously been investigated [24-29]. In the present study, eNO levels were elevated in COPD and were not influenced by steroid treatment, in accordance with previously published data [24]. This is consistent with the finding that inflammation in COPD is not suppressed by inhaled or oral corticosteroids, even at high doses $[30,31]$.

The analysis of the induced sputum showed an increased neutrophil cell count. However, no correlation was found with lung function tests, eNO or exhaled air temperature. Therefore, although there was an increased cell count of the induced sputum, this was not correlated with the other markers of inflammation.

In COPD, the final bronchial blood flow and $\Delta \mathrm{e}^{\circ} \mathrm{T}$ may depend on the balance between pro-inflammatory mediators causing vasodilation and reduced vascularity associated with the progression of the disease. It is noteworthy that even though the patients enrolled in this study were predominantly sputum producers, as shown by the low degree of emphysema assessed by $\mathrm{CT}$ scan and carbon monoxide diffusion in the lung, their $\Delta \mathrm{e}^{\circ} \mathrm{T}$ was reduced. The authors assume that this may be due to bronchial tissue remodelling and reduced blood vessels in COPD patients. Therefore, the measurement of eNO and $\Delta \mathrm{e}^{\circ} \mathrm{T}$ may complement each other, one reflecting airway inflammation and the other tissue remodelling.

Another possible explanation for the reduction in $\Delta \mathrm{e}^{\circ} \mathrm{T}$ in COPD patients is that mucus hypersecretion may damper heat exchange in the airways. However, this is unlikely as no increase in $\Delta \mathrm{e}^{\circ} \mathrm{T}$ with inhaled salbutamol was shown.

Prospective studies are necessary to investigate the association of exhaled breath temperature, disease progression and exacerbation. Further studies are necessary to investigate the correlation of these new measurements with other markers of inflammation in exhaled breath condensate and induced sputum, and their clinical utility in the follow-up of patients with chronic obstructive pulmonary disease.

\section{References}

1. Fletcher C, Peto R. The natural history of chronic airflow obstruction. BMJ 1977; 1: 1645-1648.

2. Reid A, Heard BE. Preliminary studies of human pulmonary capillaries by indian ink injection. Med Thorac 1962; 19: 599-790.

3. Cudkowicz L. The bronchial arteries in pulmonary emphysema. Thorax 1953; 8: 46-58.

4. Casiglia E, Pavan L, Marcato L, et al. Subjects with obstructive pulmonary disease tend to be chronically vasodilated. Clin Sci (Colch) 1998; 95: 287-294.

5. Rahman I, Morrison D, Donaldson K, MacNee W. Systemic 
oxidative stress in asthma, COPD, and smokers. Am J Respir Crit Care Med 1996; 154: 1055-1060.

6. Chediak AD, Elsasser S, Csete ME, Gazeroglu H, Wanner A. Effect of histamine on tracheal mucosal perfusion, water content and airway smooth muscle in sheep. Respir Physiol 1991; 84: 231-243.

7. Laitinen LA, Laitinen MA, Widdicombe JG. Dose-related effects of pharmacological mediators on tracheal vascular resistance in dogs. Br J Pharmacol 1987; 92: 703-709.

8. McDonald DM. Neurogenic inflammation in the respiratory tract: actions of sensory nerve mediators on blood vessels and epithelium of the airway mucosa. Am Rev Respir Dis 1987; 136: 65-72.

9. Bjork J, Smedegard G. Acute microvascular effects of PAFacether, as studied by intravital microscopy. Eur J Pharmacol 1983; 96: 87-94.

10. Roland M, Bhowmik A, Sapsford RJ, et al. Sputum and plasma endothelin-1 levels in exacerbations of chronic obstructive pulmonary disease. Thorax 2001; 56: 30-35.

11. Kharitonov SA, Barnes PJ. Exhaled markers of pulmonary disease. Am J Respir Crit Care Med 2001; 163: 1693-1722.

12. Pauwels RA, Buist AS, Calverley PM, Jenkins CR, Hurd SS. Global strategy for the diagnosis, management, and prevention of chronic obstructive pulmonary disease. NHLBI/ WHO Global Initiative for Chronic Obstructive Lung Disease (GOLD) Workshop summary. Am J Respir Crit Care Med 2001; 163: 1256-1276.

13. Paredi P, Kharitonov SA, Barnes PJ. Faster rise of exhaled breath temperature in asthma: a novel marker of airway inflammation? Am J Respir Crit Care Med 2002; 165: 181-184.

14. Paredi P, Loukides S, Ward S, et al. Exhalation flow and pressure-controlled reservoir collection of exhaled nitric oxide for remote and delayed analysis. Thorax 1998; 53: 775-779.

15. Bland JM, Altman DG. Statistical methods for assessing agreement between two methods of clinical measurement. Lancet 1986; 1: 307-310.

16. Kharitonov S, Alving K, Barnes PJ. Exhaled and nasal nitric oxide measurements: recommendations. The European Respiratory Society Task Force. Eur Respir J 1997; 10: 1683-1693.

17. Maestrelli P, Saetta M, Di Stefano A, et al. Comparison of leukocyte counts in sputum, bronchial biopsies, and bronchoalveolar lavage. Am J Respir Crit Care Med 1995; 152: 19261931.

18. Experimental bronchial artery occlusions in sheep. Proceeding of the 11th Aspen Emphysema Conference. Aspen, Colorado, US Department, 1968, pp. 187-189.
19. Deffebach ME, Charan NB, Lakshminarayan S, Butler J. The bronchial circulation. Am J Respir Crit Care Med 1987; 135: 463-481.

20. Gilbert IA, McFadden ERJ. Airway cooling and rewarming. The second reaction sequence in exercise induced asthma. J Clin Invest 1992; 90: 699-704.

21. Gilbert IA, Regnard J, Lenner KA, Nelson JA, McFadden ERJ. Intrathoracic airstream temperatures during acute expansions of thoracic blood volume. Clin Sci (Colch) 1991; 81: 655-661.

22. Kumar SD, Emery MJ, Atkins ND, Danta I, Wanner A. Airway mucosal blood flow in bronchial asthma. Am J Respir Crit Care Med 1998; 158: 153-156.

23. Brieva JL, Danta I, Wanner A. Effect of an inhaled glucocorticosteroid on airway mucosal blood flow in mild asthma. Am J Respir Crit Care Med 2000; 161: 293-296.

24. Paredi P, Kharitonov SA, Leak D, Ward S, Cramer D, Barnes PJ. Exhaled ethane, a marker of lipid peroxidation, is elevated in chronic obstructive pulmonary disease. $\mathrm{Am}$ J Respir Crit Care Med 2000; 162: 369-373.

25. Maziak W, Loukides S, Culpitt S, Sullivan P, Kharitonov SA, Barnes PJ. Exhaled nitric oxide in chronic obstructive pulmonary disease. Am J Respir Crit Care Med 1998; 157: 998-1002.

26. Kanazawa H, Shoji S, Yoshikawa T, Hirata K, Yoshikawa J. Increased production of endogenous nitric oxide in patients with bronchial asthma and chronic obstructive pulmonary disease. Clin Exp Allergy 1998; 28: 1244-1250.

27. Rutgers SR, van der Mark TW, Coers W, et al. Markers of nitric oxide metabolism in sputum and exhaled air are not increased in chronic obstructive pulmonary disease. Thorax 1999; 54: 576-580.

28. Clini E, Bianchi L, Pagani M, Ambrosino N. Endogenous nitric oxide in patients with stable COPD: correlates with severity of disease. Thorax 1998; 53: 881-883.

29. Papi A, Romagnoli M, Baraldo S, et al. Partial reversibility of airflow limitation and increased exhaled NO and sputum eosinophilia in chronic obstructive pulmonary disease. Am J Respir Crit Care Med 2000; 162: 1773-1777.

30. Culpitt SV, Maziak W, Loukidis S, Nightingale JA, Matthews JL, Barnes PJ. Effect of high dose inhaled steroid on cells, cytokines, and proteases in induced sputum in chronic obstructive pulmonary disease. Am J Respir Crit Care Med 1999; 160: 1635-1639.

31. Keatings VM, Jatakanon A, Worsdell YM, Barnes PJ Effects of inhaled and oral glucocorticoids on inflammatory indices in asthma and COPD. Am J Respir Crit Care Med 1997; 155: 542-548. 